\title{
Pengelolaan Endowment Fund di Perguruan Tinggi Malaysia: Studi Kasus di Universitas Teknologi Malaysia
}

\author{
Muhammad Munadi \\ IAIN Surakarta \\ munadimahdiputra@gmail.com
}

\begin{abstract}
This article aims to determine the historical development, management, the mechanism of collection, and distribution of endowment funds in UTM of Malaysia. The results show that the UTM endowment fund has been initiated through the RM 1 movement per student as well as expanded for lecturers and staff and fundraising from the company. Endowments fund has a fundraising program through every student to contribute RM 1.00, sponsored book by UTM publisher, Eternal Endowment Tower, golf tournament, recruitment alms during Ramadan and Idul Fitri and investment in finance and trust fund units. The income generation mechanism from donations are dominant than sources from projects and investment returns. Income derived from the project is greater than the income originating from the investment. The endowment fund distributors are identical to the distribution of scholarships.
\end{abstract}

\begin{abstract}
Abstrak
Artikel ini bertujuan untuk mengetahui perkembangan historis, pengelolaan, mekanisme penghimpunan, dan distribusi endowment fund di UTM Malaysia. Hasil penelitian menunjukkan bahwa Endowment fund di UTM dilakukan dengan penggalangan dana melalui gerakan 1 RM tiap mahasiswa serta diperluas untuk dosen dan staf dan penggalangan dana dari perusahaan. Endowments fund memiliki program fundraising melalui every student to contribute RM 1.00,buku sponsor oleh penerbit UTM, Eternal Endowment Tower, turnamen golf, perekrutan sedekah saat Ramadlan dan Idulfithri serta investasi di bidang keuangan dan satuan dana perwalian. Mekanisme penghimpunan pemasukan dari sumbangan masih lebih dominan dibandingkan bersumber dari proyek dan hasil investasi. Pemasukan berasal dari proyek lebih besar daripada pemasukan yang bersumber dari investasi. Pendistribusi dana endowment fund identik dengan distribusi beasiswa.
\end{abstract}

Keywords: Pricing, Product, Finance, Consumer, BSM 


\section{A. Pendahuluan}

Perguruan tinggi terutama milik negara saat ini dan yang akan datang tidak bisa hanya mengandalkan dana dari pemerintah saja. Sumber pendanaan harus lebih luas dan besar yang berasal dari semua kelompok kepentingan. Kelompok bisnis bisa melalui corporate social responsibility (CSR). Kelompok lain di luar itu bisa melalui masyarakat baik individual maupun kelompok melalui skema endowment fund atau dikenal dengan istilah dana abadi.

Sumber dana yang berasal dari endowment fund dialami perguruan tinggi di Amerika Serikat. Universitas besar banyak memiliki dana besar dari sumber ini dapat dilihat pada tabel berikut ${ }^{1}$

Tabel 1. Universitas Besar dengan Dana Endowment Besar di AS

\begin{tabular}{|c|c|c|}
\hline School name (state) & $\begin{array}{l}\text { End of fiscal year } \\
2013 \text { endowment }\end{array}$ & $\begin{array}{l}\text { U.S. News rank and } \\
\text { category }\end{array}$ \\
\hline Harvard University (MA) & $\$ 32,689,489,000$ & 2, National Universities \\
\hline Yale University (CT) & $\$ 20,708,793,000$ & 3, National Universities \\
\hline Princeton University (NJ) & $\$ 18,786,132,000$ & 1, National Universities \\
\hline tanford University (CA) & $\$ 18,688,868,000$ & $\begin{array}{l}4 \text { (tie), National } \\
\text { Universities }\end{array}$ \\
\hline $\begin{array}{l}\text { Massachusetts Institute of } \\
\text { Technology }\end{array}$ & 976,000 & 7, National Universities \\
\hline $\begin{array}{l}\text { University of Michigan- } \\
\text { Ann Arbor }\end{array}$ & $\$ 8,272,366,000$ & $\begin{array}{l}\text { 29, National } \\
\text { Universities }\end{array}$ \\
\hline $\begin{array}{l}\text { Columbia University } \\
(\mathrm{NY})\end{array}$ & $\$ 8,197,880,000$ & $\begin{array}{l}4 \text { (tie), National } \\
\text { Universities }\end{array}$ \\
\hline $\begin{array}{l}\text { Texas A\&M University- } \\
\text { College Station }\end{array}$ & $\$ 8,072,054,790$ & $\begin{array}{l}68 \text { (tie), National } \\
\text { Universities }\end{array}$ \\
\hline $\begin{array}{l}\text { University of } \\
\text { Pennsylvania }\end{array}$ & $\$ 7,741,396,000$ & $\begin{array}{l}8 \text { (tie), National } \\
\text { Universities }\end{array}$ \\
\hline $\begin{array}{l}\text { University of Notre Dame } \\
\text { (IN) }\end{array}$ & $\$ 6,959,051,000$ & $\begin{array}{l}16 \text { (tie), National } \\
\text { Universities }\end{array}$ \\
\hline
\end{tabular}

\footnotetext{
${ }^{1}$ Susannah Snider, 10 Universities With the Largest Financial Endowments., 2015, http://www.usnews.com/education/best-colleges/the-short-listcollege/articles/2015/01/13/10-universities-with-the-largest-financial-endowments.
} 
Kesepuluh perguruan tinggi di atas jumlah endowment terbesar di Amerika yang berstatus swasta sebanyak sembilan dan hanya satu universitas negeri yang masuk dalam daftar tersebut yaitu Universitas Michigan-Ann Arbor (kekayaan US\$ 8 trilyun, yang berada di ranking enam). Jumlah dana endowment terkecil tercatat sebanyak US\$ 6 trilyun yang dimiliki Universitas Notre Dame.

Universitas Princeton merupakan salah satu contoh universitas yang sangat mahir dalam mendorong alumni untuk memberikan sumbangan sehingga menjadi perguruan tinggi yang memiliki tingkat tertinggi dari alumni yang memberikan sumbangan tingkat universitas di Amerika Serikat kurang lebih 59,2 persen. Pada tahun 2008, lebih dari 33.000 alumni sarjana menyumbangkan \$ 43.600 .000 untuk almamater mereka. Sebagai hasil dari penggalangannya, lebih dari 50 persen diserap untuk anggaran operasional Princeton University ${ }^{2}$.

Data perguruan tinggi yang memiliki dana dari endowment selain perguruan tinggi di Amerika Serikat dapat dilihat dari histogram berikut:

Gambar 1. Besaran Dana Abadi Pada Universitas di Luar Amerika Serikat

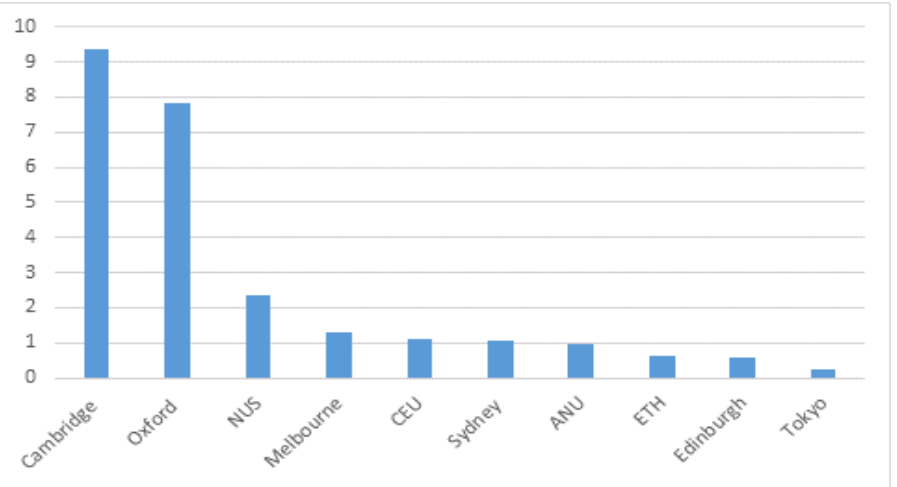

(Alex Usher, 2015)

Gambar tersebut menunjukkan bahwa dana abadi tidak hanya dimiliki perguruan tinggi di Amerika Serikat saja akan tetapi juga dimiliki perguruan tinggi di Eropa, Asia dan Australia. Menurut Alex

\footnotetext{
2 William Foster, Peter Kim, and Barbara Christiansen, "Ten Nonprofit Funding Models.," 2009, http://www.bridgespan.org/Publications-and-Tools/FundingStrategy/Ten-Nonprofit-Funding-Models.aspx\#.VVFJcIEx86h.
} 
Usher $^{3}$ bahwa di benua Asia, hanya dua universitas yang memiliki dana endowment yang besar yaitu The King Abdullah University of Science and Technology (KAUST) dan National University of Singapore (NUS). Perguruan tinggi yang pertama memiliki dana endowment sebesar USD \$ 20 Miliar dan yang kedua memiliki dana sebesar \$2.3 Miliar.

Johnstone dan Marcucci yang dikutip MENA $^{4}$ menyatakan sumbangan dalam bentuk endowment fund merupakan pendapatan penghasilan perguruan tinggi saat ini. Sementara tiga perempat dari dana tersebut telah digunakan untuk mendanai penelitian dalam lima tahun terakhir setiap tahun. Bahkan menurut Fishman ${ }^{5}$ Endowments of foundations, healthcare, social service, and cultural institutions were similarly affected.

Dalam konteks peradaban Islam menurut Sultan T. Abu-Orabi ${ }^{6}$ menyatakan lembaga pendidikan seperti Al Zaytounah (Tunisia, 734 AD), Qarawiyyun di Fez (Marroko 859AD), al-Azhar di Kairo (Mesir, 970AD) dan $\mathrm{Al}$ Mustansiryah di Iraq (984 AD) terpelihara perkembangannya menjadi universitas pertama di dunia yang pernah didirikan dan sebagian besar dari mereka didanai oleh Wakaf Islam (Endowment). Inspirasi ini menjadikan Universitas Sains dan Teknologi Raja Abdullah (King Abdullah University of Sciences and Technology = KAUST), memiliki dana abadi US \$ 10 milyar - yang terbesar keenam di dunia.

Endowment fund bisa dipergunakan untuk pengembangan fasilitas perguruan tinggi (Farra Munna Harun, Bayu Taufiq Possumah, Muhammad Hakimi Bin Mohd. Shafiai dan Abd. Halim Mohd. Noor,

3 Alex Usher, University Endowments in a Global Context, 2015, http://higheredstrategy.com/university-endowments-in-a-global-context/.

${ }^{4}$ MENA, Chapter 6: Diversifying Higher Education Revenue through Philanthropy and Endowments: Implications for the MENA Region. Siteresources. Worldbank.Org/.../Resources/Financi, 2012, 1.

5 James Fishman, "What Went Wrong: Prudent Management of Endowment Funds and Imprudent E," 204, accessed March 2018, https://digitalcommons.pace.edu/lawfaculty/958/.

6 T. Abu-Orabi Sultan, "Scientific Research \& Higher Education In The Arab World.," 2016, http://www.ub.edu/LinkingMedGulf/docs/kickoff_meeting/scientific_research.pdf.

${ }^{7}$ Farra Munna Harun et al., "Empowering Higher Education Institution: The Role Of Waqf - Malaysian Perspective. Proceedings Of The Australian Academy Of Business And Social Sciences Conference 2014 (In Partnership With The Journal Of Developing 
Dana Endowment Universitas Nasional Singapura (The National University of Singapore) even enabled the university to fund its own scholarships to foreign and international students ${ }^{8}$.

Tulisan ini bertujuan mengetahui: perkembangan endowment fund, pengelolaan endowments fund dan mekanisme penghimpunan dan distribusi endowment fund di UTM.

Penelitian ini menggunakan pendekatan kualitatif dengan jenis deskriptif. Pendekatan ini dipakai karena pengembangan dana melalui endowment fund (dana abadi) yang dilihat berdasar pada proses perencanaan sampai evaluasinya. Setting yang diambil dalam penelitian ini adalah Universitas Teknologi Malaysia di Johor Bahru Malaysia yang sedang mengembangkan strategi peningkatan kuantitas dan kualitas dana endowment. Penelitian ini akan menjadikan subyeknya adalah : Pengelola Endowment fund. Informan penelitiannya adalah jajaran pimpinan perguruan tinggi. Teknik Pengumpulan Data yang dipakai Observasi, Wawancara, dan Dokumentasi. Data yang terkumpul dilakukan keabasahan data dengan cara triangulasi sumber dan metode. Analisis data dalam penelitian ini dilakukan dengan metode non statistik dengan menggunakan model interaktif.

\section{B. Pendidikan Tinggi dan Endowment Fund}

Sistem pendidikan tinggi menurut Abdouli ${ }^{9}$ adalah sistem yang memiliki fungsi tripartit yang saling berkaitan meliputi:

a. Creators as major forces, who are academics, administrative staff and students.

b. Knowledge, which is the product designed for society and humanity as a whole, based on methods, programs and pedagogical tools.

https://www.aabss.org.au/system/files/published/AABSS2014_250.pdf.

8 Greta Nielsen, "Comparative Experiences of Middle Income Countries. This Diagnostic Has Been Commissioned by AusAID's Tertiary Education and Knowledge Sector Unit. The Views and Opinions Expressed in This Paper Are Those of the Author Only. AusAID Does Not Accept Legal Liability for Material Contained in This Document.," 2010, 84.

9 Harun et al., "Empowering Higher Education Institution: The Role Of Waqf Malaysian Perspective. Proceedings Of The Australian Academy Of Business And Social Sciences Conference 2014 (In Partnership With The Journal Of Developing Areas)." 
c. Spheres, which are institutions and conceptions of building, designed to match the educational and creative process.

Perguruan tinggi memiliki tiga fungsi. Fungsi pencipta merupakan kekuatan terdiri atas dosen, staf administrasi, dan mahasiswa. Fungsi pengetahuan yang bermanfaat bagi masyarakat dan kemanusiaan yang didasarkan pada metode, program dan alat pedagogis. Fungsi lingkungan yang dirancang untuk memadukan pendidikan dan proses kreatif. ketiganya merujuk pada pengembangan pengetahuan. Hal ini sesuai pendapat Levin ${ }^{10}$ sebagai berkut: In general, there is wide agreement that great universities have three major roles: (1) excellence in education of their students; (2) research, development and dissemination of knowledge; and (3) activities contributing to the cultural, scientific, and civic life of society. Ada tiga peran utama perguruan tinggi yaitu: (1) keunggulan dalam pendidikan mahasiswa, (2) penelitian, pengembangan dan penyebaran pengetahuan, dan (3) kegiatan yang berkontribusi terhadap budaya, ilmu, dan kehidupan sipil masyarakat.

Tugas tersebut harus pula didukung dengan regenerasi pengetahuan. Hal ini dinyatakan D'Andrea dan Gosling ${ }^{11}$ mengatakan bahwa "Higher education has a social purpose that is not merely about transmitting knowledge and skills... it should also engage students in a transformational process by encouraging critical reflections on their learning and actions." Proses transformasi ini diyakini akan makin bermakna ketika mahasiswa turut masuk ke dalam aktivitas inti universitas yakni pencarian dan penemuan pengetahuan baru.

Pencapaian tujuan dan peran di atas memerlukan biaya yang tidak sedikit, sehingga pendanaannya tidak saja berasal dari pemerintah saja dan pembayaran SPP dari mahasiswa tetapi juga berasal dana masyarakat yang bersumber dari dana masyarakat yang bersifat fleksibel. Dana tersebut bisa dipakai untuk melaksanakan fungsi perguruan tinggi, yaitu: pendidikan dan pengajaran, penelitian serta pengabdian masyarakat.

${ }^{10}$ Levin, Henry (2006). What is a world class university?, 2006,2. www.tc.columbia.edu/centers/coce/pdf_files/c12.pdf

${ }^{11}$ D'Andrea Vaneeta and Gosling David, Improving Teaching And Learning In Higher Education: A Whole Institution Approach: A Whole Institution Approach (McGraw-Hill Education (UK), 2005), 2. 
Pendidikan tinggi seperti pendapat Fishman ${ }^{12}$ bahwa Most colleges and universities of all sizes have an endowment, a fund that provides a stream of income and maintains the corpus of the fund in perpetuity.

Pendapat tersebut bermakna bahwa kebanyakan perguruan tinggi dari semua jenis ukuran memiliki dana abadi, yaitu sebuah dana yang menyediakan aliran pendapatan dan mempertahankan korpus dana lamanya. Dana abadi merupakan sumber pendanaan bagi perguruan tinggi disampaikan Jamil Salmi ${ }^{13}$ sebagai berikut: These universities have four main sources of financing: government budget funding for operational expenditures and research, contract research from public organizations and private firms, the financial returns generated by endowments and gifts, and tuition fees.

Ini berarti bahwa dana abadi merupakan dana tambahan untuk sumber pendapatan perguruan tinggi disamping sumber dana konvensional.

Pendapat yang senada disampaikan Matt Willie ${ }^{14}$ the term "endowment" refers to money that a university may not spend. That is, "[t]rue endowment funds are" given to a college "on the condition that the principal is to be preserved. . . ." While income from endowment investments may be used to fund university activities, trust law requires that institutions abide by donor restrictions.

Istilah "endowment" mengacu pada uang universitas yang tidak mungkin dihabiskan. Artinya, "dana abadi nyata" yang diberikan kepada perguruan tinggi "dengan syarat dipertahankan agar tidak habis oleh pimpinan perguruan tinggi. "Sementara pendapatan dari investasi wakaf dapat digunakan untuk mendanai kegiatan universitas, hukum kepercayaan mengharuskan lembaga mematuhi pembatasan donor.

Pendapat yang seiring dengan dua pendapat di atas dinyatakan Kathryn W. Miree \& Associates, Inc ${ }^{15}(\mathrm{tth})$ Endowment: A permanent

\footnotetext{
12 Fishman, "What Went Wrong: Prudent Management of Endowment Funds and Imprudent E," 199.

13 Jamil Salmi, The Challenge of Establishing World-Class (New York: World Bank, 2009), 23.

${ }^{14}$ Willie Matt, Taxing and Tuition: A Legislative Solution to Growing Endowments and the Rising Costs of a College Degree (BYU L., 2012), 1671, http://digitalcommons.law.byu.edu/lawreview/vol2012/iss5/6.

15 Kathryn W. Miree Kathryn W. Miree \& Associates, Inc, Five steps to a successful endowment October 10, 2012. 5 www. kathrynmireeandassociates.com
} 
fund bestowed upon an individual or institution, such as a university, museum, hospital, or foundation, to be used for a specific purpose. Endowments may be separately held funds within the charity, or separately established nonprofits holding long-term funds generally referred to as supporting organizations to the charity.

Maksud dana abadi meliputi terlihat dari pernyatan berikut ini: An endowment is created through gifts intended for the long-term support of nonprofit institutions - from churches, hospitals, and museums to colleges and universities ${ }^{16}$.

Pendapat tersebut menunjukkan bahwa maksud dana abadi adalah dukungan dana jangka panjang dari lembaga nirlaba - dari gereja-gereja, rumah sakit, dan museum untuk perguruan tinggi dan universitas. Dana tersebut menurut Association of American University bisa bersumber darimana saja dan bisa didistribusikan seperti berikut ini:

Individual donors, foundations, and corporations contribute to endowments for a variety of reasons -- to fund student scholarships, enhance ndergraduate and graduate education, create professorships, renovate or construct teaching and research facilities, and improve a wide range of campus activities, including the arts, public service, student housing, and athletics ${ }^{17}$.

Dana abadi bisa berasal dari sumbangan individu, yayasan, dan perusahaan yang berkontribusi untuk :

1. Dana beasiswa mahasiswa,

2. Meningkatkan pendidikan sarjana dan pascasarjana,

3. Meningkatkan jumlah profesor,

4. Merenovasi atau membangun fasilitas pengajaran dan penelitian, serta

5. Meningkatkan berbagai kegiatan kampus - termasuk seni, pelayanan publik, perumahan mahasiswa, dan atletik.

\footnotetext{
16 Association of American University, Understanding college and university endowments. 2007. https://www.aau.edu/sites/default/files/AAU\%20Files/Key\%20Issues/Taxation\%20\%26 $\% 20$ Finance/Undstdng-Univ-Endow.pdf

17 Association of American University, Understanding college and university endowments. 2007.

https://www.aau.edu/sites/default/files/AAU\%20Files/Key\%20Issues/Taxation\%20\%26 $\% 20$ Finance/Undstdng-Univ-Endow.pdf
} 
Penggunaan tersebut diambil bukan dari pokok dana abadi tetapi hasil dari usaha seperti yang dipaparkan Shanta Acharya and Elroy Dimson ${ }^{18}$ :

Individual endowments for specific purposes are usually pooled, creating a vehicle similar to a mutual fund or unit trust. This enables broad diversification of investments among asset classes, thereby providing an appropriate balance between return and volatility. Pooling also permits economies in oversight, investment management, and accounting costs. Though endowment assets are invested as a pool, each College maintains the identity of each component fund in their accounting record. Most university or college endowments consist of an investment pool composed of several individual funds with a wide variety of purposes and restrictions. Donors frequently specify a particular purpose for their gifts, creating endowments to fund professorships, scholarships, fellowships, prizes, books, libraries, buildings, and other miscellaneous purposes. Depending on the institution, endowment funds usually consist of gifts, some of which are restricted by donors to provide long-term funding for designated purposes, along with others that are unrestricted, which the endowed institution is free to invest and spend as it sees fit.

Dana abadi yang berasal dari individu untuk tujuan tertentu biasanya dikumpulkan, membentuk seperti reksa dana atau unit trust. Hal ini memungkinkan diversifikasi investasi aset yang luas, sehingga memberikan keseimbangan yang tepat antara return dan volatilitas. Pengumpulan juga memungkinkan seperti dalam bidang ekonomi sehingga terjadi pengawasan, manajemen investasi, dan biaya akuntansi. Meskipun aset dana abadi diinvestasikan seperti kolam renang, masingmasing perguruan tinggi mempertahankan identitas masing-masing komponen dana dalam catatan akuntansi mereka. Kebanyakan dana abadi perguruan tinggi berasal dari beberapa dana individu dengan berbagai pembatasan dan tujuan. Donor sering menentukan tujuan tertentu untuk hadiah, menciptakan wakaf untuk mendanai profesor, beasiswa, beasiswa, hadiah, buku, perpustakaan, gedung, dan tujuan lain-lain. Kesemuanya tergantung pada lembaga dana abadi, yang kadang ada beberapa yang dibatasi oleh donor untuk memberikan pendanaan jangka

18 Shanta Acharya and Elroy Dimson, , Endowment Asset Management Investment Strategies in Oxford and Cambridge (Oxford: Oxford University Press, 2007), 9. 
panjang untuk tujuan yang ditunjuk, dan ada pemberi dana memberikan kebebasan pada lembaga dana abadi untuk berinvestasi dimanapun.

Salah satu perguruan tinggi di Malaysia terinspirasi dan belajar dari perguruan tinggi di atas yaitu UTM di Johor Bahru untuk merintis dan mengembangkan dana abadi. Gambaran dananya sebagai berikut:

Tabel 2. Pendapatan Sumbangan Endowment di UTM (dalam juta

$\mathrm{RM})$

\begin{tabular}{|l|l|l|l|l|l|l|l|}
\hline Pendapatan & 2010 & 2011 & 2011 & 2012 & 2013 & 2014 & 2015 \\
\hline Sumbangan & 3,5 & 9,9 & 30 & 33,6 & 50 & 55 & 75 \\
\hline
\end{tabular}

(UTM, 2013)

Permulaan dibuat inisiasi terjadi pada tahun 2010 dan masih berkembang sampai saat ini. Perkembangan yang ada seperti yang tertulis dalam tabel di atas dengan nominal dalam juta ringgit terlihat bahwa target untuk tahun 2011 yang harus terkumpul total RM 9,9 juta (sekitar Rp 29,7 milyar dengan kurs 1 RM = Rp. 3000), ternyata terlampuai lebih dari setengahnya menjadi RM 30 juta.

\section{Deskripsi Endowment Fund di UTM}

\section{Perkembangan Endowment Fund di UTM.}

Tahun 2010 pada tanggl 17 Agustus 2010 memulai gerakan Every student to contribute RM $1.00 \mathrm{ke}$ 'Merdeka Endowment fund' melalui program 'Pengorbanan Merdeka'. Hal ini berbarengan dengan peluncuran Perayaan Kemerdekaan Malaysia ke-53 bertempat di Gedung Kanselir Sultan Ibrahim. Peluncuran ini berbarengan dengan hari Kemerdekaan Malaysia dinyatakan, "Kontribusi ini juga merupakan simbol penghargaan mahasiswa tentang pengorbanan yang dilakukan oleh generasi tua kami dalam perjuangan mereka untuk kemerdekaan negara kita. Kami menyebutnya RM1.00 ini untuk 1 siswa dan semua sumbangan akan dimasukkan ke dalam Merdeka Endowment fund karena kita tidak harus bergantung sepenuhnya pada sumber pendanaan pemerintah. Universitas terbaik di seluruh dunia telah menerapkan semacam ini pendanaan jauh sebelum Malaysia (W-DFTI/01).

Inisiasi yang dilakukan UTM terinspirasi Universitas peringkat tinggi seperti Harvard University di Amerika Serikat dukungan sekitar 70 persen dari siswa dengan pemberian beasiswa dari dana abadi mereka sendiri. 
Endowment fund berawal pada wakaf, kemudian berubah dikarenakan ada alasan mendasar. Hal ini dinyatakan berikut:

Awalnya inspirasinya berasal dari wakaf dalam konsep Islam. Akan tetapi kalau memakai istilah wakaf berakibat pada subyek wakaf hanya pada umat Islam sehingga umat non Islam kurang tertarik. Kemudian kita ubah menjadi istilah endowment fund sehingga memperluas subyek pemberinya (W-DFTI/01).

Hal ini lebih ditegaskan sebagai berikut: "Kalau disebut sebagai wakaf akan memperkecil peluang bagi penyumbang yang tidak beragama Islam, maka dengan menamai sebagai endowment fund akan lebih universal. Walaupun hakekatnya sama". (W-DFTI/02).

Pernyataan tersebut menunjukkan bahwa perubahan nama dari wakaf ke endowment fund dalam kerangka untuk memperluas target pemberi dana dengan tidak mendasarkan latar belakang agamanya. Disamping itu diperkuat apa yang tercantum dalam Ringkasan Eksekutif Blueprint Pendidikan Malaysia 2015-2025 (Pendidikan Tinggi) menyatakan :

Implementasi inisiatif roadmap melalui menyusun praktek terbaik dalam "playbooks" pada daerah kritis perbaikan untuk diadopsi oleh Lembaga Pendidikan Tinggi: diantaranya Membangun sumber pendapatan alternatif, termasuk dana abadi dan wakaf. Memperkenalkan insentif untuk pembentukan dana abadi atau wakaf oleh Lembaga Pendidikan Tinggi milik swasta dan publik, termasuk hibah yang cocok dan pembebasan pajak;

Untuk mencapai hasil ini, Kementerian akan menghubungkan pendanaan pemerintah untuk kinerja, reformasi mekanisme pembiayaan mahasiswa yang ada, dan mendorong Lembaga Pendidikan Tinggi untuk mendiversifikasi sumber pendanaan. Inisiatif utama meliputi:

Meningkatkan formula pendanaan untuk lembaga pendidikan tinggi milik publik dengan mengganti hibah dengan terhubung pada kinerja dan pendanaan siswa, menerapkan kontrak kinerja lima tahunan, dan menargetkan investasi pemerintah di bidang-bidang prioritas;

Meningkatkan kinerja PTPTN dan keberlanjutan dengan meningkatkan tingkat pembayaran, beralih ke pinjaman pendapatan kontingen, dan menghubungkan akses ke pinjaman mahasiswa dengan kinerja dan kualitas standar Lembaga Pendidikan Tinggi;

Penciptaan insentif (incentivising) dana abadi dan dana wakaf, serta mendorong kontribusi untuk pendidikan tinggi, misalnya, melalui 
penyediaan dana pendamping untuk Lembaga Pendidikan Tinggi selama periode penggalangan dana awal.

Data tersebut menunjukkan bahwa dana abadi yang diinisiasi oleh UTM sejalan dengan kebijakan baru kementerian Pendidikan Tinggi Malaysia.

Sejak tiga tahun lalu di berbagai universitas negeri di Malaysia, mulai membentuk dan mengkampanyekan endowment fund. Dari segi pembiayaan yang diterima, sebenarnya universitas negeri di Malaysia tidak mempunyai banyak kesulitan keuangan seperti negara tetangganya; berhubung dengan gaji pegawai, dana riset serta biaya operasional dan maintenance rutin diberikan dengan nominal yang bisa membuat mereka fleksibel bekerja dan berprestasi. Namun bila dituntut lebih dalam hal kualitas riset kelas dunia, bagaimanapun itu perlu investasi yang lebih besar lagi (jutaan ringgit atau milyaran rupiah), dimana pihak pemerintah pusat tentu tidak akan mudah mengabulkan permintaan tersebut. Misal untuk membeli alat khusus untuk keperluan laboratorium riset dengan harga RM 5 juta (sekitar Rp 15 milyar), tentu deretan permintaan ini susah untuk diluluskan. Kondisi lain adalah persaingan untuk mendapat mahasiswa terbaik (khususnya untuk S1), dengan ketersediaan pinjaman biaya kuliah dari pemerintah, mahasiswa terbaik bisa kuliah dimana yang dia inginkan; namun bila ada insentif bebas biaya kuliah di satu kampus tentu akan menimbulkan daya tarik yang susah untuk dilewatkan. Maka membentuk endowment fund sesuatu inisiatif yang cerdik untuk menangangi hal itu.

Perguruan tinggi negeri di Malaysia sangat aktif melakukan penggalangan dana dan promosi untuk endowment fund. Pada tahap ini yang paling banyak dana yang dikumpulkan melalui sumbangansumbangan yang diberikan oleh staf, mahasiswa, alumni dan rekanan. Kultur sedekah masih bersifat individual dan belum begitu melembaga seperti di Amerika Serikat, maka cara untuk mengumpanpun dihubungkan dengan kewajiban pajak. Dalam sistem pajak penghasilan di Malaysia, maka wajib pajak bisa mendapat keringanan bayar pajak bila dia menyumbangkan $7 \%$ nominal pajak penghasilannya pada lembaga yang diakui, dalam hal ini universitas negeri. Maka dorongan untuk membayar sejumlah uang yang sama ke negara dari penghasilan didapat tapi disalurkan langsung ke institusi tempat bekerja menjadi daya tarik sendiri bagi staf dosen dan administasi; pada saat yang sama ini akan menunjukkan indikasi kesukarelaan bersedekah dan kecintaan pegawai yang mengabdi. Jenis lain pemberian sedekahpun dilakukan 
dilakukan diantaranya menyumbangkan royalti buku, hadiah dalam bentuk uang tunai dari suatu perlombaan baik oleh mahasiswa atau staf, maupun kegiatan fund raising khusus untuk kampanye dan penyadaran pentingnya endowment fund.

UTM sejak tahun 2010 memiliki prospek yang besar dari tahun ke tahun dilihat dari pemasukan dana abadinya. Pemasukannya berasal dari beberapa bentuk sumbangan meliputi : sumbangan, proyek dan investasi. Gambarannya sebagai berikut:

Tabel 3. Perkembangan Endowment fund di UTM

\begin{tabular}{|c|c|c|c|c|c|c|c|}
\hline Sumbangan & & & & & & & \\
\hline Pemasukan & 2010 & 2011 & 2011 & 2012 & 2013 & 2014 & 2015 \\
\hline Sumbangan & 3,5 & 9,9 & 30 & 33,6 & 50 & 55 & 75 \\
\hline Proyek & 0 & 10 & 2,6 & 19,5 & 45 & 37 & 40 \\
\hline Investasi & 0 & 0,1 & 0,1 & 0,5 & 5 & 3 & 5 \\
\hline Total & 3,5 & 20 & 32,7 & 53,6 & 100 & 95 & 120 \\
\hline Beasiswa & 0 & 1 & 0,3 & 1,3 & 10 & 6 & 8 \\
\hline $\begin{array}{l}\text { Endowment } \\
\text { Chair }\end{array}$ & 0 & 1 & 0 & 0,3 & 0 & 2 & 3 \\
\hline $\begin{array}{l}\text { Proyek } \\
\text { Khusus }\end{array}$ & 0 & 1 & 0 & 2 & 20 & 7 & 9 \\
\hline Total & 0 & 3 & 0,3 & 3,6 & 30 & 15 & 20 \\
\hline Total Dana & 3,5 & 17 & 32,4 & 50 & 70 & 80 & 100 \\
\hline
\end{tabular}

Pada tabel (nominal dalam juta ringgit) terlihat bahwa target untuk tahun 2011 yang harus terkumpul total RM 20 juta (sekitar Rp 60 milyar), ternyata terlampuai lebih dari setengahnya menjadi RM 32,7 juta. Pengeluaran yang dilakukan pun masih kecil, yaitu RM 300 ribu, dimana semua dalam bentuk beasiswa prestasi untuk sekitar 25 mahasiswa jenjang Strata 1. Tahun 2012 jumlah penerima beasiswa drastis melonjak menjadi seratus orang lebih. Nominal beasiswa ini sangat layak untuk skala Malaysia, dimana mahasiswa mendapatkan RM 12 ribu/tahun. Besaran ini merupakan jumlah yang lebih besar dari pinjaman perguruan tinggi per bulan-nya (biasanya sekitar RM 700 per bulan), namun uang RM 1 ribu/bulan ini bukan pinjaman namun pemberian tanpa ikatan karena prestasi yang didapat. Dilihat dari tabel, proyeksi tahun 2020 nanti dana endowment mencapai RM 600 juta, dan alokasi untuk beasiswa mencapai RM 30 juta; dengan jumlah itu maka semua mahasiswa Strata1 yang masuk secara otomatis mendapat 
beasiswa, suatu daya tarik yang luar biasa, yang pada saat yang sama pihak universitas bisa melakukan seleksi yang ketat hanya mahasiswa berbakat dan berprestasi tinggi saja yang layak diterima.

\section{Pengelolaan Endowments fund.}

Dana abadi UTM telah dimulai yang dikumpulkan dari berbagai pihak dan keuntungan investasi yang akan diberikan kepada semua mahasiswa UTM tahun pertama pada tahun mendatang 2020. Dana sejauh ini telah dikumpulkan RM 5.4 juta dan mereka berencana untuk mengumpulkan lebih banyak tahun ini melalui berbagai program seperti buku sponsor oleh Penerbit UTM, Profesorship Chair, Eternal Endowment Tower, turnamen golf dan investasi di bidang keuangan dan satuan dana perwalian (W-DFTI/03).

Sebagai awalan, RM 1 juta telah dialokasikan sebagai beasiswa untuk 100 mahasiswa atas senilai RM 10,000 per orang untuk jangka waktu setahun mulai semester 2011/2012. Para siswa yang terdaftar di sesi akademik 2011/2012 berhak untuk mengajukan permohonan untuk beasiswa dan siapapun sukses akan menerima beasiswa sampai mereka lulus tergantung pada kinerja mereka.

Penerima penghargaan beasiswa tidak akan obligasi oleh UTM dan mereka bebas untuk bekerja dengan organisasi lain setelah lulus mereka. Program ini disebut Program Implementasi mUTM untuk Implementasi Keunggulan mulai 9 Mei 2011.

Mulai dari September tahun ini, Universiti Teknologi Malaysia (UTM) akan melaksanakan lima Program Jalur Excellence (ETP) untuk meningkatkan keterampilan profesional dan soft skill di kalangan mahasiswa.

Daerah inti jalur penghargaan untuk keunggulan akademik, kewirausahaan, olahraga, kepemimpinan dan Tahfiz bertujuan untuk meningkatkan kerja kualitas lulusan (W-DFTI/04). Menurutnya program ini akan membantu mengembangkan bakat, keterampilan, semangat dan kreativitas siswa yang akan membuat UTM lulusan berbeda dari lulusan universitas lain. Setiap program akan mengidentifikasi 10 siswa berprestasi yang akan menerima alokasi RM5 ribu setahun dan hanya yang terbaik akan dipilih untuk bergabung dengan grup ini (W-DFTI/05).

Siswa yang datang untuk belajar di UTM tidak hanya studi rekayasa dan disiplin ilmu khusus lainnya, tetapi bakat khusus mereka dan kualitas khusus akan dibina dan dimanfaatkan secara maksimal (WDFTI/06). Subyek penelitian ini menambahkan bahwa selain dari ETP, 
UTM juga memperkenalkan program wakaf sebagai bagian dari inisiatif untuk meningkatkan kualitas studi sarjana di universitas. Untuk tahun 2011, UTM menargetkan RM20 juta untuk dana abadi dan total 100 siswa yang dipilih akan menerima Beasiswa Endowment kurang lebih RM10 ribu setiap tahun untuk mendanai studi mereka di UTM. Pada tahun 2020, sebagian besar mahasiswa UTM akan diberikan beasiswa jika nominal dana abadi RM 600 juta dari tabungan telah dicapai dan mereka tidak perlu lagi bergantung pada pemerintah untuk pinjaman studi atau beasiswa. Hal ini dinyatakan responden, "Ini akan mengurangi ketergantungan pada lembaga pemerintah seperti Dana Korporasi National Pendidikan Tinggi (PTPTN) yang diharapkan dapat mengalokasikan RM 20 miliar pinjaman pada tahun 2020," (WDFTI/07). Pernyataan tersebut menunjukkan bahwa ketika dana abadi semakin besar akan menjadikan ada otonomi dalam penyelenggaraan perguruan tinggi karena tidak berada di bawah bayang-bayang negara.

\section{Mekanisme Penghimpunan dan Distribusi Dana Endowment fund Di UTM.}

Tahun 2010 pada tanggl 17 Agustus 2010 memulai gerakan perekrutan dana melalui Every student to contribute $R M 1.00$ ke 'Merdeka Endowment fund' melalui program 'Pengorbanan Merdeka'. Hal ini berbarengan dengan peluncuran Perayaan Kemerdekaan Malaysia ke-53 bertempat di Gedung Kanselir Sultan Ibrahim. Peluncuran ini berbarengan dengan hari Kemerdekaan Malaysia dalam kerangka mengembangkan jiwa pengorbanan pada generasi muda seperti yang diungkpa oleh responden, "Kontribusi ini juga merupakan simbol penghargaan mahasiswa tentang pengorbanan yang dilakukan oleh generasi tua kami dalam perjuangan mereka untuk kemerdekaan negara kita." (W-DFTI/08).

Responden ini menguatkan bahwa, "Kami menyebutnya RM 1.00 ini untuk 1 mahasiswa dan semua sumbangan akan dimasukkan ke dalam Merdeka Endowment fund karena kita tidak harus bergantung sepenuhnya pada sumber pendanaan pemerintah. Universitas terbaik di seluruh dunia telah menerapkan semacam ini pendanaan jauh sebelum Malaysia (W-DFTI/08).

Mekanisme penghimpunan dana yang lainnya dipakai melalui web http:/giving.utm.my/ dan melalui kampanye sumbangan endowment fund UTM dengan Paket Ramadlan dan Syawal tiap tahun. 
Kampanye ini ditujukan kepada staf, mahasiswa, alumni UTM, individu dan perusahaan. Para penyumbang diberikan kompensasi sebagai berikut:

Tabel 4. Insentif bagi Penyumbang Dana Abadi UTM

\begin{tabular}{|l|l|}
\hline Sumbangan (RM) & Insentif \\
\hline Melebihi RM 10000 & $\begin{array}{l}\text { Dijemput menghadiri majelis berbuka } \\
\text { bersama DYMM Canselor atau Pro- } \\
\text { Canselor UTM atau majelis setara }\end{array}$ \\
\hline RM 5001-RM 10000 & $\begin{array}{l}\text { Mendapat undangan sebagai VIP dalam } \\
\text { 3 Majelis rasmi UTM }\end{array}$ \\
\hline RM 1001 - RM 5000 & $\begin{array}{l}\text { Menerima cenderamata khas Universiti } \\
\text { pada majelis rasmi UTM }\end{array}$ \\
\hline Kurang RM 1000 & $\begin{array}{l}\text { Menerima cenderamata penghargaan } \\
\text { UTM }\end{array}$ \\
\hline
\end{tabular}

(modifikasi dari news utm, 2015)

Disamping itu melalui model Menara Endowment. Menara Endowmen adalah komitmen UTM untuk mengumpulkan dana dalam rangka menciptakan budaya yang menghidupkan pengetahuan dan ekosistem intelektual yang subur di universitas. Upaya ini sejalan dengan inisiatif dari Kementerian Pendidikan dan praktek institusi terkenal di penggalangan dana untuk tujuan pengetahuan.

Pengelola dana abadi UTM dalam mengumpulkan dana melalui sponsorship dari pihak internal dan eksternal kampus pada acara yang diselenggarakan UTM. Sponsorship dikenai kontribusi sehingga diberikan kompensasi pada individu, organisasi atau perusahaan dapat menayangkan nama-nama mereka, gambar atau merek di tempat acara.

Sponsorship semacam itu sejalan dengan inisiatif dari Kementerian Pendidikan dan praktek universitas terkenal dalam penggalangan dana abadi. Dengan demikian sponsorship bermanfaat:

a. Memenuhi syarat untuk keringanan pajak

b. Merek, produk dan promosi layanan

c. Berhak menggunakan fasilitas UTM dengan paket khusus

d. Mampu melakukan promosi di tempat yang disponsori dengan biaya terpisah untuk warna perusahaan, logo atau counter khusus

e. Paket khusus dari ruang iklan: website, bulding fisik dan wilayah yang disediakan. 
Usaha yang dilakukan oleh pengelola untuk penggalangan dana abadi sejak tahun 2010 sampai dengan tahun 2015 mengalami peningkatan seperti tabel berikut ini:

Tabel 5. Perkembangan Endowment fund di UTM

\begin{tabular}{|l|l|l|l|l|l|l|l|}
\hline Pemasukan & 2010 & 2011 & 2011 & 2012 & 2013 & 2014 & 2015 \\
\hline Sumbangan & 3,5 & 9,9 & 30 & 33,6 & 50 & 55 & 75 \\
\hline Proyek & 0 & 10 & 2,6 & 19,5 & 45 & 37 & 40 \\
\hline Investasi & 0 & 0,1 & 0,1 & 0,5 & 5 & 3 & 5 \\
\hline Total & 3,5 & 20 & 32,7 & 53,6 & 100 & 95 & 120 \\
\hline
\end{tabular}

(modifikasi dari news utm, 2015)

Sumbangan yang dimaksud dalam tabel di atas berasal dari semua pemangku kepentingan termasuk staf universitas, mahasiswa, Alumni dan individu, organisasi perusahaan dan lain-lain dari dalam dan luar negeri.

Secara internal penggalangan dana dilakukan tiap fakultas. Pada tahun 2013 gambaran perolehan dananya sebagai berikut:

Tabel 6. Hasil Penggalangan internal UTM

\begin{tabular}{|l|l|}
\hline PTJ/FAKULTI & JUMLAH (RM) \\
\hline Canselori & $63,117.50$ \\
\hline Fakulti Geoinformasi Dan Harta Tanah & $55,546.00$ \\
\hline IBS & $33,507.00$ \\
\hline $\begin{array}{l}\text { Pejabat Hal Ehwal Mahasiswa Dan } \\
\text { Alumni }\end{array}$ & $32,072.00$ \\
\hline Pejabat Tnc (P\&I) & $25,570.00$ \\
\hline UTM Kl & $24,129.84$ \\
\hline Pusat Pengurusan Penyelidikan & $20,900.00$ \\
\hline $\begin{array}{l}\text { Fakulti Sains Komputer \& Sistem } \\
\text { Maklumat }\end{array}$ & $19,896.00$ \\
\hline Fakulti Kejuruteraan Elektrik & $18,385.00$ \\
\hline Fakulti Tamadun Islam & $17,880.00$ \\
\hline
\end{tabular}

(modifikasi dari news utm, 2015)

Disamping itu penghimpunan dana di atas terlihat tidak hanya melalui sumbangan saja tetapi juga melalui beragam pemasukan. Walaupun masih kecil pemasukan di luar sumbangan, tetapi tabel tersebut menunjukkan bahwa terobosan untuk mengembangkan dana sudah diupayakan. Kegiatannya melalui proyek dan investasi. 
Dana yang dimiliki dialokasikan terlihat dalam tabel berikut ini:

Tabel 7. Distribusi Dana Abadi

\begin{tabular}{|l|l|l|l|l|l|l|l|}
\hline Pengeluaran & 2010 & 2011 & 2011 & 2012 & 2013 & 2014 & 2015 \\
\hline Beasiswa & 0 & 1 & 0,3 & 1,3 & 10 & 6 & 8 \\
\hline $\begin{array}{l}\text { Endowment } \\
\text { Chair }\end{array}$ & 0 & 1 & 0 & 0,3 & 0 & 2 & 3 \\
\hline $\begin{array}{l}\text { Proyek } \\
\text { Khusus }\end{array}$ & 0 & 1 & 0 & 2 & 20 & 7 & 9 \\
\hline Total & 0 & 3 & 0,3 & 3,6 & 30 & 15 & 20 \\
\hline
\end{tabular}

(modifikasi dari news utm, 2015)

Distribusi dana abadi memang tidak banyak dibandingkan dari pemasukan. Akan tetapi gambaran yang lebih detil dipergunakan untuk : Beasiswa Sarjana bagi mahasiswa UTM yang memiliki reputasi luar biasa secara akademik, Sponsorship untuk Professorship Chair, Publikasi bahan ilmiah serta Pelaksanaan program berdampak tinggi untuk menanamkan budaya pengetahuan di UTM.

Pengembangan dana abadi perlu dilakukan dalam kerangka "pembesaran" dana pokok sekaligus memperbesar bagi hasil dari dana abadi yang diinvestasikan. Dana yang tidak diinvestasikan hanya akan mengurangi dana yang dimiliki. UTM juga melakukan hal yang sama tetapi tidak ada data yang mendukung dana yang diinvestasikan pada perusahaan apa dan besar dana tidak terungkap.

Data yang terungkap hanyalah berkaitan dengan besaran dana yang diinvestasikan. Berikut gambarannya:

Tabel 8. Perkembangan Endowment fund di UTM

\begin{tabular}{|l|c|c|c|c|c|c|c|c|c|c|c|c|}
\hline $\begin{array}{c}\text { Pemasu } \\
\text { kan }\end{array}$ & $\begin{array}{c}201 \\
0\end{array}$ & $\%$ & $\begin{array}{c}201 \\
1\end{array}$ & $\%$ & 2012 & $\%$ & $\begin{array}{c}20 \\
13\end{array}$ & $\%$ & $\begin{array}{c}20 \\
14\end{array}$ & $\%$ & $\begin{array}{c}20 \\
15\end{array}$ & $\%$ \\
\hline $\begin{array}{l}\text { Sumba } \\
\text { ngan }\end{array}$ & 3,5 & 1 & 30 & $\begin{array}{l}0, \\
9\end{array}$ & 33,6 & 0,63 & 50 & 0,5 & 55 & 0,58 & 75 & 0,63 \\
\hline Proyek & 0 & 0 & 2,6 & $\begin{array}{l}0, \\
1\end{array}$ & 19,5 & 0,36 & 45 & 0,5 & 37 & 0,39 & 40 & 0,33 \\
\hline $\begin{array}{l}\text { Investa } \\
\text { si }\end{array}$ & 0 & 0 & 0,1 & 0 & 0,5 & 0,01 & 5 & 0,1 & 3 & 0,03 & 5 & 0,04 \\
\hline Total & 3,5 & & 32,7 & & 53,6 & & $\begin{array}{l}10 \\
0\end{array}$ & & 95 & & 12 & \\
\hline
\end{tabular}

(modifikasi dari news utm, 2015) 
Tabel tersebut menunjukkan bahwa pemasukan dari sumbangan masih lebih dominan dibandingkan bersumber dari proyek dan hasil investasi. Akan tetapi tiap tahun aspek pemasukan di luar sumbangan proyek dan investasi - mengalami peningkatan prosentasenya. Pemasukan berasal dari proyek lebih besar daripada pemasukan yang bersumber dari investasi. Bahkan pemasukan bersumber dari investasi mengalami pasang surut dari tahun ke tahun.

Penghimpunan dana diseiringkan dengan pendistribusian dana abadi. Gambaran distribusinya sebagai berikut:

Tabel 9. Distribusi Dana Abadi di UTM

\begin{tabular}{|c|c|c|c|c|c|c|c|c|c|c|c|c|}
\hline Pengeluaran & $\begin{array}{l}20 \\
10\end{array}$ & $\%$ & $\begin{array}{l}20 \\
11\end{array}$ & $\%$ & $\begin{array}{l}20 \\
12\end{array}$ & $\%$ & $\begin{array}{l}20 \\
13\end{array}$ & $\%$ & $\begin{array}{l}20 \\
14\end{array}$ & $\%$ & $\begin{array}{l}20 \\
15\end{array}$ & $\%$ \\
\hline Beasiswa & 0 & 0 & $\begin{array}{l}0, \\
3\end{array}$ & 1 & $\begin{array}{l}1, \\
3\end{array}$ & 0,36 & 10 & 0,3 & 6 & 0,4 & 8 & 0,4 \\
\hline $\begin{array}{l}\text { Endowment } \\
\text { Chair }\end{array}$ & 0 & 0 & 0 & 0 & $\begin{array}{l}0, \\
3\end{array}$ & 0,08 & 0 & 0 & 2 & 0,13 & 3 & 0,15 \\
\hline $\begin{array}{l}\text { Proyek } \\
\text { Khusus }\end{array}$ & 0 & 0 & 0 & 0 & 2 & 0,56 & 20 & 0,7 & 7 & 0,47 & 9 & 0,45 \\
\hline Total & 0 & & $\begin{array}{l}0, \\
3\end{array}$ & & $\begin{array}{l}3, \\
6\end{array}$ & & 30 & & 15 & & 20 & \\
\hline
\end{tabular}

(modifikasi dari news utm, 2015)

Distribusi dana di atas terlihat bahwa pada tahun awal yaitu tahun 2011 identik dengan distribusi beasiswa. Pada tahun berikutnya sudah mencakup pengeluaran beasiswa, endowment chair dan proyek khusus. Pada tahun 2013 sampai dengan tahun 2015 proporsi yang paling besar distribusi paling besar pada proyek khusus untuk pengembangan perguruan tinggi. Jika diperingkatkan adalah peringkat pertama ada pada pengeluaran proyek khusus baru kemudian disusul beasiswa dan yang terakhir dialokasikan pada endowment chair.

Pemasukan dan pengeluaran dana abadi mengalami kenaikan dan penuruan. Gambarannya sebagai berikut:

Tabel 10. Perbandingan Pemasukan dengan Pengeluaran Dana Abadi

\begin{tabular}{|l|l|l|l|l|l|l|}
\hline Pemasukan & 2010 & \multicolumn{1}{|c|}{2011} & \multicolumn{1}{|c|}{2012} & 2013 & 2014 & 2015 \\
\hline Sumbangan & 3,5 & 30 & 33,6 & 50 & 55 & 75 \\
\hline Proyek & 0 & 2,6 & 19,5 & 45 & 37 & 40 \\
\hline Investasi & 0 & 0,1 & 0,5 & 5 & 3 & 5 \\
\hline Total & 3,5 & 32,7 & 53,6 & 100 & 95 & 120 \\
\hline Pengeluaran & 2010 & 2011 & 2012 & 2013 & 2014 & 2015 \\
\hline Beasiswa & 0 & 0,3 & 1,3 & 10 & 6 & 8 \\
\hline
\end{tabular}




\begin{tabular}{|l|l|l|l|l|l|l|}
$\begin{array}{l}\text { Endowment } \\
\text { Chair }\end{array}$ & 0 & 0 & 0,3 & 0 & 2 & 3 \\
\hline $\begin{array}{l}\text { Proyek } \\
\text { Khusus }\end{array}$ & 0 & 0 & 2 & 20 & 7 & 9 \\
\hline Total & 0 & 0,3 & 3,6 & 30 & 15 & 20 \\
\hline$\%$ M - K & 0 & 0,0091743 & 0,0671642 & 0,3 & 0,1578947 & 0,1666667 \\
\hline
\end{tabular}

(modifikasi dari news utm, 2015)

Tabel di atas terlihat bahwa prosentase pemasukan dan pengeluaran dana abadi mengalami peningkatan yang signifikan. Berawal dari prosentase nol berubah menjadi berurutan menjadi $0,91 \%$ berubah $6,72 \%, 30 \%, 15,8 \%$ dan yang terakhir $15,8 \%$.

\section{Endowment Fund dan Keberlangsungan Perguruan Tinggi}

Fakta di atas menunjukkan bahwa endowment fund bukan hanya mendukung keamanan keuangan lembaga perguruan tinggi (PT) saja. Namun ini sudah menjadi penanda berkaitan dengan prestasi dan reputasi dari sebuah universitas. Perguruan tinggi tersohor yang memang mempunyai dukungan keuangan yang tak terbatas bisa menginvestasikan dana abadinya. PT cukup menggantungkan keuntungan investasinya untuk bisa memberikan beasiswa pada mahasiswa yang berpotensi memiliki prestasi serta memberikan tunjangan jabatan guru besar pada pakar yang paling unggul yang ada di dunia. Kondisi semacam ini sangat ingin dilakukan oleh universitas negeri dimanapun berada.

Jika PT bisa semacam ini, maka tepat yang dinyatakan Renald Kasali $^{19}$ bahwa kampus-kampus besar dunia sebagai pengawal masa depan bangsa bekerja keras menggalang dana abadi, agar para penerus tidak kalah bagus dari generasi pendahulunya. Yang boleh diambil hanyalah hasil dari investasi dana abadi itu, bukan "hutan abadinya". Kampus dimanapun tak boleh menjadi "pemalak" bagi generasi penerus bangsanya yang akan memimpin masa depan, melainkan harus menjadi wahana kontribusi, tempat perjuangan para pemimpin. Inilah logika dasar universitas-universitas kelas dunia.

Dana wakaf atau dengan nama lain yaitu dana endowment dalam khazanah peradaban Islam memang sudah lama. Mohd Afendi Mat Rani

19 Rhenald Kasali, 2014, Memanfaatkan Potensi Besar Dana Abadi Universitas. Kompas, 
and Asmah Abdul Aziz ${ }^{20}$ menyatakan Endowment is one of the Islamic institutions that has existed since the time of Prophet Muhammad SAW. It serves as a catalyst for economic growth and development of the Muslims. Dana abadi bisa menjadi sebuah katalis pertumbuhan ekonomi dan pengambangan masyarakat muslim.

Abul Hasan and Mohammad Abdus Shahid yang dikutip Zariana binti Sahari dan Muhammad Ridhwan bin Ab. Aziz ${ }^{21}$ menyatakan bahwa the endowment assets are considered as the trust asset, where the trustee role is to protect the assets for the benefit of the beneficiaries. It means that all fixed assets of endowment have the potential to generate benefits for the public and contribute towardsprosperity. Ini berarti bahwa semua aset tetap abadi memiliki potensi untuk menghasilkan manfaat bagi masyarakat dan berkontribusi terhadap kesejahteraan.

Farra Munna Harun, Bayu Taufiq Possumah, Muhammad Hakimi Bin Mohd. Shafiai dan Abd. Halim Mohd. Noor ${ }^{22}$ menyatakan Waqf as an endowment can be used as a source of funds to facilitate education program, especially higher education institutions.

Rhenald Kasali ${ }^{23}$ (2014) menyatakan universitas-universitas terkenal dibangun dengan kesadaran dana abadi. Sumbernya bukan hanya berasal dari sumbangan mahasiswa melalui sumbangan pendidikan melalui SPP atau yang sejenis, melainkan dana-dana yang dicari melalui kerja luar biasa dari para pimpinan perguruan tinggi bersama-sama dengan civitas academica-nya (terutama alumni dan para mitra perguruan tinggi). Justru dengan dana abadi itulah, mahasiswa-

20 Mohd Afendi Mat Rani And Asmah Abdul Aziz, 2010, Waqf Management And Administration In Malaysia: Its Implementation From The Perspective Of Islamic Law. Malaysian Accounting Review, Special Issue Vol. 9 No. 2, 115-121, 2010. 115

21 Zariana binti Sahari and Muhammad Ridhwan bin Ab. Aziz, 2014, An Exploratory Study On Instruments Of Waqf Financing. 2014, 4 www.researchgate.net/.../268516483_AN_EXPLO

${ }^{22}$ Farra Munna Harun et al., "Empowering Higher Education Institution: The Role Of Waqf - Malaysian Perspective. Proceedings Of The Australian Academy Of Business And Social Sciences Conference 2014 (In Partnership With The Journal Of Developing Areas).," 2014, 12,

23 Rhenald Kasali, 2014, Memanfaatkan Potensi Besar Dana Abadi Universitas. Kompas, 
mahasiswa dapat belajar dengan baik, beraktifitas dengan riang gembira, lalu reputasi kampuspun akan menjadi besar.

Endowment fund yang diinvestasikan sehingga memperbesar besaran pemasukan dana merujuk dan mengikuti langkah yang dilkukan oleh Harvard university. Universitas ini pada tahun 2006 menginvestasikan dana milik yayasannya untuk membeli saham senilai US\$ 29,2 miliar yang memberikan return 16,7\%. Imbal hasil dari investasi menjadi penyumbang terbesar sumber penerimaan yakni mencapai $42 \%$. Sedangkan biaya kuliah porsinya hanya sekitar $19 \%{ }^{24}$. Hal tersebut diperkuat Rhenald Kasali ${ }^{25}$ bahwa hasil investasi dari dana abadi (Endowment fund) milik Universitas Harvard yang besarnya 36,4 miliar dollar AS, atau setara Rp 440 triliun. Dana itu pulalah yang banyak mengalir ke berbagai sektor keuangan dan sektor riil di Indonesia, diinvestasikan dalam bentuk proyek-proyek infrastruktur dan energi, yang hasil keuntungannya dijadikan dana pengembangan Harvard University.

Hasil investasi dana abadi yang dipakai kampus-kampus kelas dunia mengembangkan tri dharma perguruan tinggi yang unggul diantaranya dukungan dana para profesor, mahasiswa pascasarjana dan sarjana dalam melakukan penelitian visioner, berisiko tinggi, dan bernilai tinggi, riset-riset fenomenal, perpustakaan yang lengkap dan berteknologi tinggi, mengembangkan pelayanan, fasilitas-fasilitas pendidikan, termasuk hotel dan asrama mahasiswa yang dilengkapi wifi gratis. Selain itu mahasiswa-mahasiswa yang hebat tidak hanya diberikan uang kuliah, melainkan juga biaya hidup ${ }^{26}$.

Paparan tersebut bila diterapkan di Indonesia masih terbatas pada perguruan tinggi yang berstatus swasta atau perguruan tinggi badan hukum $(\mathrm{PTBH})$. Implementasinya bisa merujuk pada peraturan UU No. 12 Tahun 2012, tetapi secara lebih operasional bisa merujuk pada Peraturan Pemerintah Republik Indonesia Nomor 58 Tahun 2013

\footnotetext{
${ }^{24}$ Darmin, 2015, PT di Indonesia Diminta Kreatif Kelola Dana Yayasan. Medan Bisnis. Kamis, 19 Mar 2015 07:41 WIB - http://mdn.biz.id/n/153112/

25 Rhenald Kasali, 2014, Memanfaatkan Potensi Besar Dana Abadi Universitas. Kompas, 13 Oktober 2014. http://bisniskeuangan.kompas.com/read/2014/10/13/130806626/Memanfaatkan.Potensi. Besar.Dana.Abadi.Universitas

${ }^{26}$ R. Leigh Steven, "Endowments And The Future Of Higher Education.," 2014, 1, https://www.colorado.edu/artsandsciences/news-events/message-dean/endowments-andfuture-higher-education.
} 
Tentang Bentuk Dan Mekanisme Pendanaan Perguruan Tinggi Negeri Badan Hukum. Peraturan yang bisa dirujuk pada Pasal 3 ayat 2 yang berbunyi:

(2) Selain dialokasikan dari anggaran pendapatan dan belanja negara sebagaimana dimaksud pada ayat (1), Pendanaan penyelenggaraan Pendidikan Tinggi oleh PTN Badan Hukum juga dapat bersumber dari:

a. masyarakat;

b. biaya pendidikan;

c. pengelolaan dana abadi dan usaha-usaha PTN Badan Hukum;

d. kerja sama Tridharma;

e. pengelolaan kekayaan negara yang diberikan oleh Pemerintah dan pemerintah daerah untuk kepentingan pengembangan Pendidikan Tinggi; dan/atau;

f. sumber lain yang sah.

(3) Sumber pendanaan PTN Badan Hukum sebagaimana dimaksud pada ayat (2) merupakan pendapatan PTN Badan Hukum yang dikelola secara otonom ${ }^{27}$.

Pasal tersebut diperkuat pada peraturan yang sama pada pasal yang berbeda yaitu pada Pasal 10 yang berbunyi ${ }^{28}$ :

(1) PTN Badan Hukum dapat memperoleh dana dari kegiatan usaha dengan mendirikan dan/atau memiliki badan usaha, pengelolaan dana abadi, dan pengelolaan hak kekayaan negara yang hak pengelolaannya diberikan oleh Pemerintah dan/atau pemerintah daerah yang dilakukan sesuai dengan ketentuan peraturan perundang-undangan.

Mendasarkan pada paparan di atas, perguruan tinggi di Indonesia terutama yang berstatus PT BH dan swasta bisa mengadopsi yang dilakukan oleh UTM dalam pengelolaan dana abadi baik perekrutan dan pendistibusian. Dana abadi ini memungkinkan ada jaminan mutu pendanaan pendidikan tinggi agar tidak hanya selalu tergantung pada anggaran dari pemerintah dan sumbangan pendidikan dari wali siswa/mahasiswa.

${ }^{27}$ UU No. 12 Tahun 2012 tentang Perguruan Tinggi

${ }^{28}$ UU No. 12 Tahun 2012 tentang Perguruan Tinggi 


\section{E. Kesimpulan}

Endowment fund di UTM sudah dimulai tahun 2009 dengan memulai penggalangan dana melalui gerakan $1 \mathrm{RM}$ tiap mahasiswa. Kemudian diperluas untuk dosen dan staf serta penggalangan dana dari perusahaan. Endowments fund memiliki program fundraising melalui Every student to contribute RM 1.00, buku sponsor oleh penerbit UTM, Eternal Endowment Tower, turnamen golf, perekrutan sedekah saat Ramadlan dan Idulfithri serta investasi di bidang keuangan dan satuan dana perwalian. Mekanisme penghimpunan pemasukan dari sumbangan masih lebih dominan dibandingkan bersumber dari proyek dan hasil investasi. Akan tetapi tiap tahun aspek pemasukan di luar sumbangan proyek dan investasi - mengalami peningkatan prosentasenya.

\section{Daftar Pustaka}

Acharya, Shanta, and Elroy Dimson. , Endowment Asset Management Investment Strategies in Oxford and Cambridge. Oxford: Oxford University Press, 2007.

Association of American University, Understanding college and university endowments. 2007. https://www.aau.edu/sites/default/files/AAU\%20Files/Key\%20Iss ues/Taxation\%20\%26\%20Finance/Undstdng-Univ-Endow.pdf

Darmin, PT di Indonesia Diminta Kreatif Kelola Dana Yayasan. Medan Bisnis. Kamis, 19 Mar 2015 07:41 WIB http://mdn.biz.id/n/153112/

Fishman, James. "What Went Wrong: Prudent Management of Endowment Funds and Imprudent E." Accessed March 5, 2018. https://digitalcommons.pace.edu/lawfaculty/958/.

Foster, William, Peter Kim, and Barbara Christiansen. "Ten Nonprofit Funding Models.," 2009. http://www.bridgespan.org/Publications-and-Tools/FundingStrategy/Ten-Nonprofit-Funding-Models.aspx\#.VVFJcIEx86h.

Harun, Farra Munna, Bayu Taufiq Possumah, Muhammad Hakimi Bin Mohd, Shafiai, and Abd. Halim Mohd. Noor. "Empowering Higher Education Institution: The Role Of Waqf - Malaysian 
Perspective. Proceedings Of The Australian Academy Of Business And Social Sciences Conference 2014 (In Partnership With The Journal Of Developing Areas).," 2014. https://www.aabss.org.au/system/files/published/AABSS2014_25 $0 . p d f$.

Kathryn W. Miree Kathryn W. Miree \& Associates, Inc, Five steps to a successful endowment October 10, 2012. 5 www. kathrynmireeandassociates.com

Levin, Henry (2006). What is a world class university? www.tc.columbia.edu/centers/coce/pdf_files/c12.pdf

Matt, Willie. Taxing and Tuition: A Legislative Solution to Growing Endowments and the Rising Costs of a College Degree. BYU L., 2012.

http://digitalcommons.law.byu.edu/lawreview/vol2012/iss5/6.

MENA. Chapter 6: Diversifying Higher Education Revenue through Philanthropy and Endowments: Implications for the MENA Region. $\quad$ Siteresources.Worldbank.Org/.../Resources/Financi, 2012.

Mohd Afendi Mat Rani And Asmah Abdul Aziz, 2010, Waqf Management And Administration In Malaysia: Its Implementation From The Perspective Of Islamic Law. Malaysian Accounting Review, Special Issue Vol. 9 No. 2, 115-121, 2010. 115

Nielsen, Greta. "Comparative Experiences of Middle Income Countries. This Diagnostic Has Been Commissioned by AusAID's Tertiary Education and Knowledge Sector Unit. The Views and Opinions Expressed in This Paper Are Those of the Author Only. AusAID Does Not Accept Legal Liability for Material Contained in This Document.," 2010.

Rhenlad Kasali, 2014, Memanfaatkan Potensi Besar Dana Abadi Universitas. $\quad$ Kompas, $13 \quad$ Oktober 2014. http://bisniskeuangan.kompas.com/read/2014/10/13/130806626/ Memanfaatkan.Potensi.Besar.Dana.Abadi.Universitas

Salmi, Jamil. The Challenge of Establishing World-Class. New York: World Bank, 2009. 
Snider, Susannah. 10 Universities With the Largest Financial Endowments., 2015. http://www.usnews.com/education/bestcolleges/the-short-list-college/articles/2015/01/13/10-universitieswith-the-largest-financial-endowments.

Steven, R. Leigh. "Endowments And The Future Of Higher Education.," 2014. https://www.colorado.edu/artsandsciences/newsevents/message-dean/endowments-and-future-higher-education.

Sultan, T. Abu-Orabi. "Scientific Research \& Higher Education In The Arab World.," 2016. http://www.ub.edu/LinkingMedGulf/docs/kickoff_meeting/scienti fic_research.pdf.

Usher, Alex. University Endowments in a Global Context, 2015. http://higheredstrategy.com/university-endowments-in-a-globalcontext/.

Vaneeta, D'Andrea, and Gosling David. Improving Teaching And Learning In Higher Education: A Whole Institution Approach: A Whole Institution Approach. McGraw-Hill Education (UK), 2005.

Zariana binti Sahari and Muhammad Ridhwan bin Ab. Aziz, 2014, An Exploratory Study On Instruments Of Waqf Financing. 2014, 4 www.researchgate.net/.../268516483_AN_EXPLO

UU No. 12 Tahun 2012 tentang PT 